\title{
Elisitasi Saponin dalam Kultur Kalus Ginseng Jawa (Talinum paniculatum Gaertn.) Menggunakan Asam Salisilat
}

\author{
Elicitation of Saponin in Callus Culture of Javanese Ginseng \\ (Talinum paniculatum Gaertn.) using Salicylic Acid
}

\author{
Putri Pono ${ }^{1}$, Ratih Restiani ${ }^{1^{*}}$, dan Dwi Aditiyarini ${ }^{1}$ \\ ${ }^{1}$ Fakultas Bioteknologi, Universitas Kristen Duta Wacana, Yogyakarta, Indonesia
}

\begin{abstract}
Abstrak
Ginseng Jawa (Talinum paniculatum Gaertn.) digunakan dalam pengobatan tradisional karena mengandung senyawa metabolit sekunder berupa saponin, tannin, alkaloid, kuinon, steroid, polifenol, flavonoid, dan minyak atsiri. Dari beberapa senyawa metabolit sekunder tersebut, saponin merupakan metabolit sekunder yang dominan dihasilkan oleh ginseng jawa dan diketahui memiliki banyak efek farmakologi. Elisitasi melalui kultur in vitro khususnya kultur kalus dapat digunakan dalam upaya meningkatkan kandungan saponin menggunakan asam salisilat. Penelitian ini bertujuan untuk mengetahui pengaruh konsentrasi asam salisilat dan waktu elisitasi terhadap pertumbuhan kalus dan produksi saponin dalam kultur kalus Talinum paniculatum. Induksi dan produksi kalus T. paniculatum menggunakan media MS dengan kombinasi 2,4-D 2 $\mathrm{mg} / \mathrm{L}+$ kinetin $3 \mathrm{mg} / \mathrm{L}$. Kalus yang telah memasuki fase stationer (pada hari ke 58) digunakan untuk proses elisitasi. Elisitasi kalus menggunakan variasi konsentrasi asam salisilat $0,5 \mathrm{mM}, 0,10 \mathrm{mM}, 0,15 \mathrm{mM}, 0,20$ $\mathrm{mM}, 0,25 \mathrm{mM}, 0,30 \mathrm{mM}, 0,35 \mathrm{mM}$ dan waktu inkubasi 3 hari, 6 hari, dan 9 hari. Ekstrak kalus selanjutnya diidentifikasi menggunakan KLT untuk mengetahui kandungan saponinnya melalui luas noda saponin. Penambahan konsentrasi asam salisilat sebesar $(0,05-0,35 \mathrm{mM})$ dan waktu elisitasi (3-9 hari) pada kultur kalus T.paniculatum berpengaruh terhadap peningkatan biomassa kalus $(0,056-0,069$ gram $)$ dibandingkan kontrol (0,054 gram) dan kandungan saponin dalam kalus. Kandungan saponin tertinggi sebesar 0,565 $\mathrm{cm}^{2}$ pada perlakuan konsentrasi asam salisilat $0,30 \mathrm{mM}$ dengan waktu inkubasi 6 hari.
\end{abstract}

Kata kunci : elisitasi, asam salisilat, kultur in vitro, T. paniculatum, saponin

\begin{abstract}
Talinum paniculatum Gaertn. is a plant that is efficacious in traditional medicine because of its secondary metabolite compounds content, such as saponins, tannins, alkaloids, quinine, steroids, polyphenols, flavonoids, and essential oils. To increase the production of saponin from T. paniculatum through in vitro culture, an effective method such as elicitation is needed. Salicylic acid is an abiotic elicitor that is often used to increase the production of secondary metabolites. This study aimed to find out the influence of salicylic acid concentration and elicitation time on biomass of callus and saponin accumulation in T. paniculatum leaf explants. Callus production of T. paniculatum was carried out in MS medium with a combination of 2.4-D $2 \mathrm{mg} / \mathrm{L}$ and kinetin $3 \mathrm{mg} / \mathrm{L}$. Elicitation was performed on callus that has entered the stationary phase with variations in the treatment of salicylic acid concentrations of $0.5 \mathrm{mM}, 0.10 \mathrm{mM}, 0.15 \mathrm{mM}, 0.20 \mathrm{mM}, 0.25$ $m M, 0.30 \mathrm{mM}$, and incubation times of 3 days, 6 days, and 9 days. Dried callus was then extracted and tested using Thin Layer Chromatography (TLC) to determine its saponin content. The addition of salicylic acid concentration (0.05 - $0.35 \mathrm{mM}$ ) and elicitation time (3-9 days) in T. paniculatum callus culture had an effect on increasing callus biomass (0.056 - 0.069 grams) compared to control (0.054 grams). The largest TLC saponin stain area $(0.565 \mathrm{~cm} 2)$ was produced at salicylic acid concentration treatment of $0.30 \mathrm{mM}$ with an incubation time of 6 days.
\end{abstract}

Keywords: elicitation, salicylic acid, in vitro culture, T. paniculatum, saponin.

\footnotetext{
*Corresponding author:

Ratih Restiani

Fakultas Bioteknologi Universitas Kristen Duta Wacana

Jl. Wahidin Sudirohusodo 5-25 Yogyakarta, Indonesia 55224

Email :ratih.restiani@staff.ukdw.ac.id,
} 


\section{Pendahuluan}

Talinum paniculatum Gaertn. atau yang dikenal dengan nama Ginseng Jawa merupakan salah satu tanaman yang digunakan sejak dahulu dalam pengobatan tradisional. T. paniculatum mengandung senyawa metabolit sekunder berupa saponin, tannin, alkaloid, kuinon, steroid, polifenol, flavonoid, dan minyak atsiri (Setyani, 2016). Saponin merupakan salah satu metabolit sekunder yang terakumulasi paling banyak pada bagian akar T.paniculatum serta diketahui memiliki efek farmakologi sebagai afrodisiak dan analog dengan ginsenoside yang dimiliki oleh Ginseng Korea (Faizal and Sari, 2019; Manuhara et al., 2015). Pemanfaatan saponin T. paniculatum dalam bidang farmasi membutuhkan konsistensi kuantitas maupun kualitas senyawa metabolit sekundernya. Perbanyakan vegetatif secara tradisional tidak dapat menjamin kualitas dan kuantitas metabolit sekunder yang optimal. Oleh karena itu, dibutuhkan metode lain yaitu melalui elisitasi kultur in vitro untuk mengoptimalkan kuantitas serta kualitas metabolit sekunder.

Kultur in vitro merupakan salah satu metode yang dapat digunakan dalam memproduksi metabolit sekunder. Kelebihan kultur in vitro dalam memproduksi metabolit sekunder yaitu tidak membutuhkan waktu yang lama dalam membudidayakan tanaman, memerlukan lahan yang relatif terbatas, waktu kultur yang relatif singkat dan metabolit sekunder yang dihasilkan dapat terjamin kuantitas dan kualitasnya serta berkelanjutan karena tidak dipengaruhi oleh terbatasnya sumber tanaman, musim serta faktor lingkungan kultur yang dapat dikendalikan (Purwianingsih et al., 2018). Kultur kalus merupakan salah satu tipe kultur in vitro yang umum digunakan dalam memproduksi metabolit sekunder. Hal ini disebabkan karena kalus memiliki semua informasi genetik pada sel tumbuhan sehingga kalus memiliki kemampuan dalam biosintesis metabolit sekunder pada tanaman target. Produksi metabolit sekunder melalui kalus juga lebih menguntungkan karena tidak membutuhkan waktu yang lama dalam menghasilkan metabolit sekunder tertentu, tidak dipengaruhi oleh faktor musim serta lebih berkelanjutan produksi metabolitnya dan memudahkan proses ekstraksinya (Efferth, 2019). Namun salah satu kelemahan yang seringkali ditemui dalam produksi metabolit sekunder melalui kultur in vitro khususnya adalah metabolit sekunder yang relatif rendah sehingga membutuhkan metode spesifik yaitu elisitasi (Purwianingsih et al., 2018). Elisitasi merupakan salah satu metode yang efektif dalam meningkatkan biosintesis dan akumulasi metabolit sekunder tertentu dalam kultur in vitro tanaman. Elisitor yang digunakan dapat berupa molekul biotik maupun abiotik yang dapat menginduksi atau meningkatkan biosintesis senyawa metabolit sekunder spesifik. Efektivitas penggunaan elisitor dalam meningkatkan metabolit sekunder tertentu sangat dipengaruhi oleh beberapa faktor seperti jenis elisitor, konsentrasi elisitor, waktu elisitasi, usia kultur, tipe kultur (Halder et al., 2019).

Asam salisilat merupakan salah satu elisitor yang banyak dipelajari sebagai sinyal molekul stres untuk menanggapi patogen pada tanaman serta dapat meningkatkan produksi metabolit sekunder tanaman. Penelitian oleh Faizal dan Sari (2019), menunjukkan asam salisilat mampu meningkatkan kandungan saponin hingga 1,3 kali lipat dari kontrol. Asam salisilat dapat meningkatkan produksi saponin dalam kultur akar adventif, namun informasi mengenai penggunaan asam salisilat dalam kultur kalus masih terbatas. Oleh karena itu, penelitian ini bertujuan untuk mengetahui pengaruh konsentrasi asam salisilat dan waktu elisitasi terhadap biomassa kalus dan kandungan saponin eksplan daun Talinum paniculatum.

\section{Materi dan Metode}

Penelitian dilaksanakan di Laboratorium Biologi Dasar Fakultas Bioteknologi Universitas Kristen Duta Wacana (UKDW), Yogyakarta dengan metode eksperimental dengan desain rancangan acak lengkap faktorial untuk menguji interaksi perlakuan konsentrasi asam salisilat dan waktu elisitasi terhadap biomassa kalus dan akumulasi 
kandungan saponin kultur kalus eksplan daun T. paniculatum. Alat yang digunakan adalah botol kultur, Laminar Air Flow (LAF), Autoclave, pinset, scalpel, alumunium foil, pengaduk, timbangan nalitik, gelas ukur, $\mathrm{pH}$ meter, gelas erlenmeyer, cawan petri, bunsen, kertas label, plat KLT (Kromatografi Lapis Tipis), mikropipet, kompor, kertas saring, microtube, dan tabung reaksi. Bahan yang digunakan adalah eksplan daun tanaman Ginseng Jawa (urutan ke-2 atau ke-3 dari bagian pucuk umur 3-4 minggu) yang diperoleh dari Merapi Farma Herbal Kaliurang, media MS (myo-inositol, sukrosa, agar, 2,4-D $2 \mathrm{mg} / \mathrm{L}$ dan kinetin $3 \mathrm{mg} / \mathrm{L}$, makronutrien, larutan stok mikronutrient, iron, vitamin) tween, detergen cair, aquades steril, asam salisilat, etanol absolute, 2-Propanol, dan anisaldehid- $\mathrm{H}_{2} \mathrm{SO}_{4}$.

\section{Pembuatan Medium Murashige and Skoog dan Media Elisitasi}

Pembuatan media MS 1 liter dilakukan dengan mencampurkan bahan makronutrien yang terdiri dari $\mathrm{NH}_{4} \mathrm{NO}_{3} 1,65 \mathrm{~g} / \mathrm{L}, \mathrm{KNO}_{3} 1$ $\mathrm{g} / \mathrm{L}, \mathrm{MgSO} 4.7 \mathrm{H}_{2} \mathrm{O}$ 0,37 g/L, dan $\mathrm{KH}_{2} \mathrm{PO} 4$ $0,17 \mathrm{~g} / \mathrm{L}$, lalu ditambahkan larutan stok mikronutrien $1 \mathrm{ml} / \mathrm{L}$, larutan stork iron 5 $\mathrm{ml} / \mathrm{L}$, stok vitamin $4 \mathrm{ml} / \mathrm{L}$, Myo-inositol 0,1g/L, ZPT dengan kombinasi 2,4-D 2 ppm dan Kinetin 3 ppm lalu ditambahkan aquades $940 \mathrm{ml}$. Selanjutnya dilakukan pengukuran derajat keasaman $(\mathrm{pH})$ menggunakan $\mathrm{pH}$ meter pada media dengan kisaran 5,7 - 5,8. Media yang telah diatur pHnya kemudian ditambahkan agar dan dipanaskan sampai agar terlarut. Media kemudian dituang ke dalam botol kultur dengan volume media kurang lebih $20 \mathrm{ml}$ lalu ditutup menggunakan aluminium foil dan perkamen. Botol kultur yang berisi media MS kemudian disterilkan menggunakan autoclave dengan suhu $120^{\circ} \mathrm{C}$ selama 20 menit dengan tekanan $15 \mathrm{lbs}$. Setelah proses sterilisasi selesai media disimpan ke dalam ruang kultur.

Pembuatan media elisitor dilakukan sama seperti komposisi dalam media MS lalu ditambahkan asam salisilat sesuai dengan konsentrasi perlakuan yang akan diberikan yaitu 0,5 mM, 0,10 mM, 0,15 mM, 0,20 mM, 0,25 mM, 0,30 mM, 0,35 mM.

\section{Sterilisasi dan Inokulasi Eksplan}

Sebelum dilakukan inokulasi kalus, alat, bahan, dan ruang kerja laminar air flow terlebih dahulu disterilisasi. Sterilisasi bahan terbagi dalam dua tahap, pra sterilisasi dan sterilisasi, tahap pra sterilisasi daun T.paniculatum dicuci menggunakan air mengalir lalu direndam ke dalam larutan detergen $10 \%$ dan 3 tetes tween 80 digojok perlahan selama empat puluh lima detik, dibilas menggunakan aquades sebanyak tiga kali pada bilasan terakhir menggunakan aquades steril sebelum dimasukkan ke dalam petri steril. Tahap sterilisasi dilakukan dalam Laminari Air Flow (LAF) dimana eksplan daun T. paniculatum dimasukkan ke dalam erlenmeyer steril lalu direndam menggunakan alkohol $50 \%$ selama 3 menit, kemudian dibilas menggunakan aquades steril sebanyak tiga kali dan dimasukkan ke dalam cawan petri steril.

Inokulasi eksplan daun ke dalam medium MS dilakukan dengan cara mengambil daun yang telah disterilisasi dengan pinset steril kemudian dipotong dengan ukuran $1 \mathrm{~cm} \mathrm{x}$ $1 \mathrm{~cm}$ dan ditanam ke dalam media dengan bagian abaksial yang kontak dengan media. Bagian mulut botol dipanaskan di atas api bunsen untuk mencegah kontaminasi. Lalu botol kultur ditutup dengan aluminium foil dan plastik wrap serta diberi label.

\section{Elisitasi}

Elisitasi dilakukan setelah kalus berumur 58 hari atau memasuki fase stasioner (Wijaya et al., 2020). Elisitasi dilakukan dengan memindahkan kalus ke dalam media elisitor dengan konsentrasi asam salisilat 0,5 $\mathrm{mM}, 0,10 \mathrm{mM}, 0,15 \mathrm{mM}, 0,20 \mathrm{mM}, 0,25 \mathrm{mM}$, 0,30 mM, 0,35 mM. Kalus diinkubasi selama 3, 6, dan 9 hari. Kalus yang telah diinokulasi lalu dikeringkan mengunakan oven pada suhu $50^{\circ} \mathrm{C}$ sampai diperoleh berat kering konstan lalu data berat kering digunakan sebagai data biomassa kalus.

\section{Ekstraksi kalus}

Ekstraksi kalus T.paniculatum dilakukan berdasarkan modifikasi metode penelitian Manuhara et al. (2015). Kalus yang telah dielisitasi, dipanen berdasarkan perlakuan waktu inkubasi kemudian ditimbang untuk mendapatkan berat basah lalu dikeringkan 
menggunakan oven pada suhu $50^{\circ} \mathrm{C}$ sampai diperoleh berat kering yang konstan. Kalus kemudian ditimbang untuk memperoleh berat kering dan dihaluskan menggunakan mortar. Bubuk kalus sebanyak 0,1g diekstraksi menggunakan etanol 96\% sebanyak $10 \mathrm{~mL}$ kemudian dipanaskan dalam waterbath selama 45 menit dengan suhu $80^{\circ} \mathrm{C}$, ekstrak disaring kemudian dipekatkan hingga $0,2 \mathrm{~mL}$ menggunakan penangas air $80^{\circ} \mathrm{C}$.

\section{Identifikasi Saponin menggunakan Kromatografi Lapis Tipis (KLT)}

Identifikasi saponin ekstrak kalus T.paniculatum menggunakan KLT dilakukan dengan modifikasi metode yang dilakukan Manuhara et al. (2015). Larutan standar yang digunakan adalah standar saponin (Merck) 5\%+1 mL etanol. Plat silika gel GF 254 berukuran $10 \times 8 \mathrm{~cm}$ dipanaskan kedalam oven dengan suhu $100^{\circ} \mathrm{C}$ selama 1 jam, lalu $3 \mu \mathrm{L}$ ekstrak dan standar saponin ditotol menggunakan mikropipet. Kemudian dielusi dengan menggunakan fase gerak 2-propanol : air dengan perbandingan 14 : 3. Untuk penentuan bercak pemisahan pada KLT dilakukan dengan menyemprotkan 0,5 $\mathrm{mL}$, anisaldehid, $10 \mathrm{~mL}$ asam asetat, $85 \mathrm{~mL}$ etanol, dan $5 \mathrm{~mL}$ asam sulfat kemudian di oven dengan suhu $110^{\circ} \mathrm{C}$ selama 5-6 menit Noda yang terbentuk diamati di bawah sinar UV 254 nm (Setyani et al.,2016).

\section{Hasil \\ Induksi Kalus Ginseng Jawa (Talinum paniculatum Gaertn.)}

Induksi kalus dilakukan melalui inokulasi eksplan daun T. paniculatum ke dalam media MS dengan penambahan ZPT 2 mg/L 2,4-D dan $3 \mathrm{mg} / \mathrm{L}$ kinetin. Pengamatan terhadap pertumbuhan kalus dilakukan setiap dua hari sekali. Selanjutnya kalus yang telah memasuki fase stasioner (pada hari ke-58) (Gambar 1.) digunakan dalam elisitasi asam salisilat pada berbagai variasi konsentrasi $(0,005-0,35 \mathrm{mM})$ dan waktu elisitasi ( 3 - 9 hari).

\section{Pengaruh Konsentrasi dan Waktu Elisitasi Asam Salisilat terhadap Biomassa Kalus Ginseng Jawa (Talinum paniculatum) \\ Pengaruh elisitasi terhadap pertumbuhan kalus T.paniculatum pada berbagai konsentrasi dan waktu elisitasi ditunjukkan melalui histogram pada Gambar 2.}

\section{Idnetifikasi Saponin menggunakan Kromatografi Lapis Tipis (KLT)}

Identifikasi saponin dalam ekstrak kalus eksplan daun ginseng jawa (Talinum paniculatum) dilakukan dengan menggunakan Kromatografi Lapis Tipis (KLT). Identifikasi terhadap saponin secara semi-kuantitatif dilakukan melalui pengukuran luas noda yang terbentuk. Hasil identifikasi saponin dalam ekstrak kalus T.paniculatum

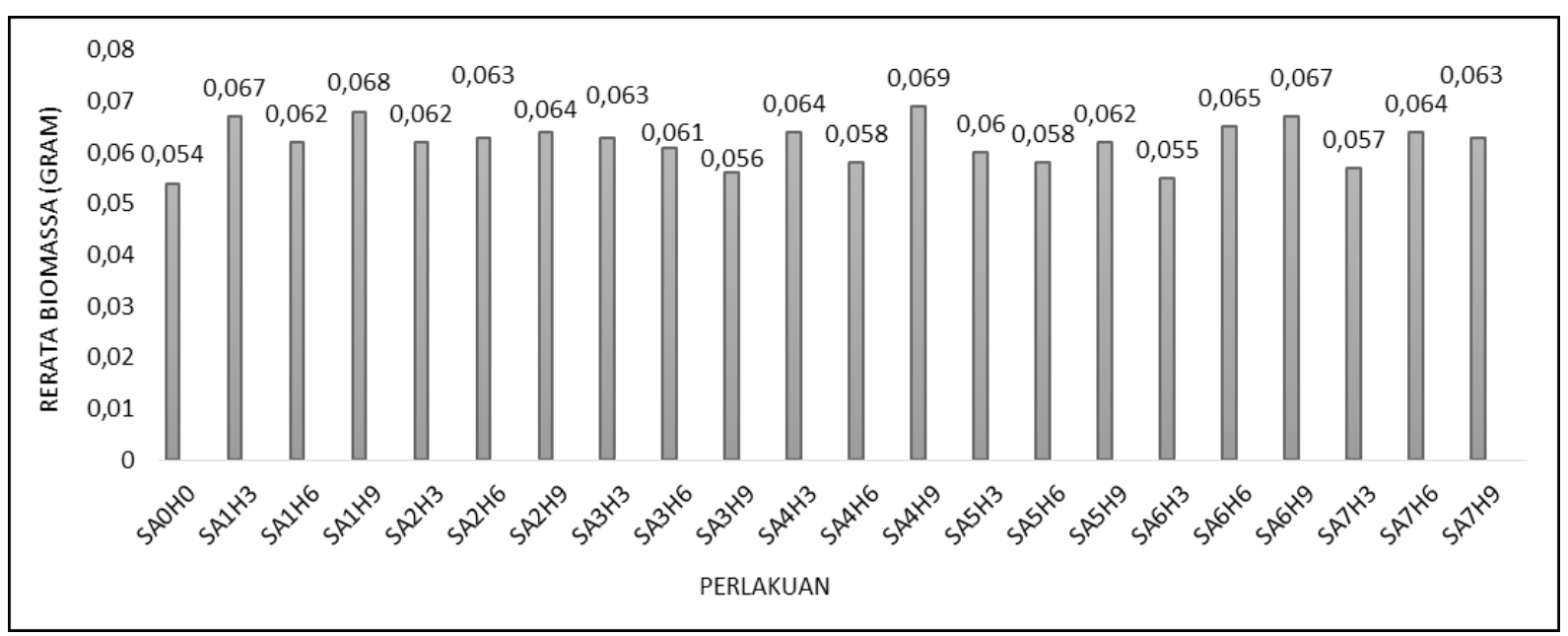

Gambar 1. Kalus eksplan daun Talinum paniculatum fase stasioner (hari ke-58) pada media MS+ 2mg/L 2,4-D+3 $\mathrm{mg} /$ L Kinetin 


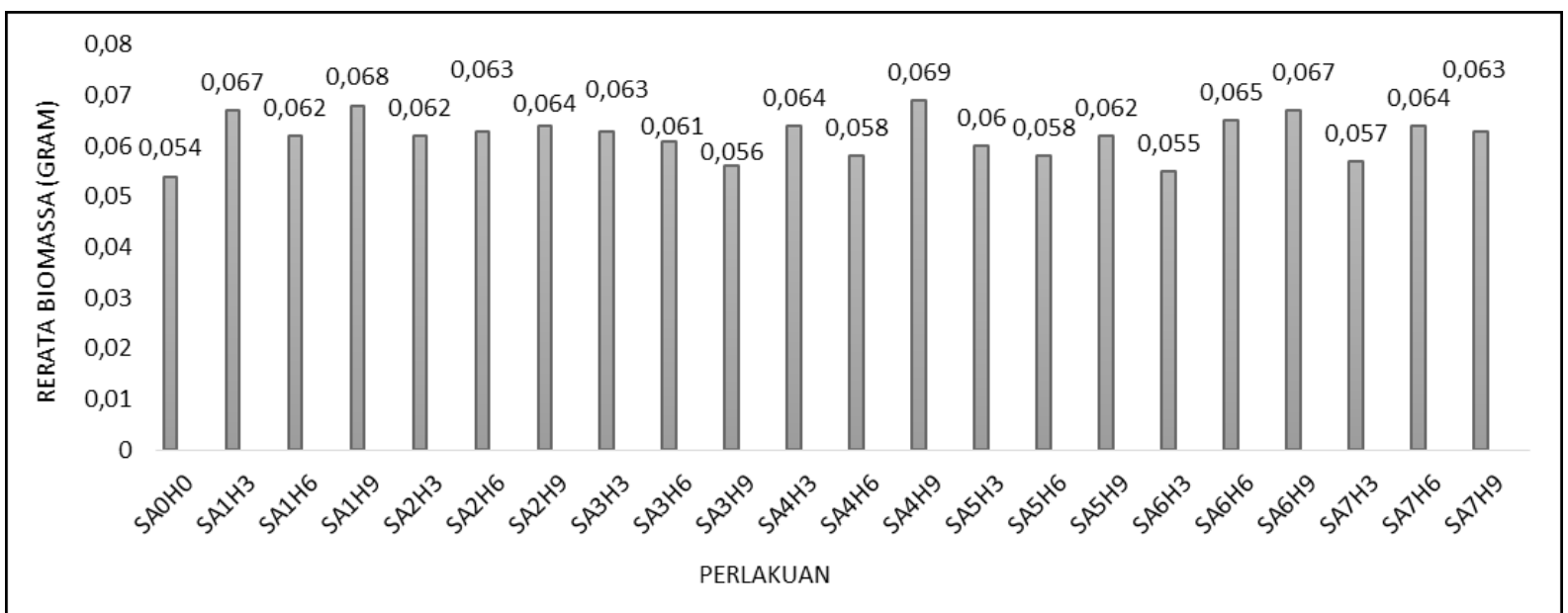

Gambar 2 Diagram biomassa kalus T. paniculatum. Keterangan : Konsentrasi asam Salisilat : $\mathrm{SA}_{0}=0 \mathrm{mM}, \mathrm{SA}_{1}=0,05$ $\mathrm{mM}, \mathrm{SA}_{2}=0,10 \mathrm{mM}, \mathrm{SA}_{3}=0,15 \mathrm{mM}, \mathrm{SA}_{4}=0,20 \mathrm{mM}, \mathrm{SA}_{5}=0,25 \mathrm{mM}, \mathrm{SA}_{6}=0,30 \mathrm{mM}, \mathrm{SA}_{7}=0,35 \mathrm{mM}$. Waktu Inkubasi $\mathrm{H}_{0}=0$ Hari, $\mathrm{H}_{3}=3$ Hari, $\mathrm{H}_{6}=6$ Hari, $\mathrm{H}_{9}=9$ Hari

Tabel1. Luas Noda Saponin Ekstrak Kalus T.paniculatum

\begin{tabular}{ccc}
\hline Sampel & $R f$ & Luas Noda Saponin $\left(\mathrm{cm}^{2}\right)$ \\
\hline Standar Saponin $5 \%$ & 0,66 & 0,063 \\
\hline$S A_{0} H_{0}$ & 0,61 & 0,251 \\
$S A_{1} H_{3}$ & 0,62 & 0,471 \\
$S A_{1} H_{6}$ & 0,62 & 0,330 \\
$S A_{1} H_{9}$ & 0,64 & 0,275 \\
$S A_{2} H_{3}$ & 0,64 & 0,236 \\
$S A_{2} H_{6}$ & 0,65 & 0,283 \\
$S A_{2} H_{9}$ & 0,65 & 0,220 \\
$S A_{3} H_{3}$ & 0,64 & 0,314 \\
$S A_{3} H_{6}$ & 0,62 & 0,188 \\
$S A_{3} H_{9}$ & 0,64 & 0,220 \\
$S A_{4} H_{3}$ & 0,65 & 0,330 \\
$S A_{4} H_{6}$ & 0,62 & 0,314 \\
$S A_{4} H_{9}$ & 0,64 & 0,283 \\
$S A_{5} H_{3}$ & 0,66 & 0,424 \\
$S A_{5} H_{6}$ & 0,65 & 0,275 \\
$S A_{5} H_{9}$ & 0,62 & 0,283 \\
$S A_{6} H_{3}$ & 0,64 & 0,220 \\
$S A_{6} H_{6}$ & 0,64 & 0,565 \\
$S A_{6} H_{9}$ & 0,65 & 0,440 \\
$S A_{7} H_{3}$ & 0,64 & 0,377 \\
$S A_{7} H_{6}$ & 0,65 & 0,275 \\
$S A_{7} H_{9}$ & 0,64 & 0,385 \\
\hline
\end{tabular}

menggunakan KLT dapat dilihat pada Gambar 3 dan Tabel 1. Hasil pengamatan menunjukkan adanya bercak hijau setelah disemprot menggunakan anisaldehide$\mathrm{H}_{2} \mathrm{SO}_{4}$ diduga sebagai saponin pada ekstrak kalus T. paniculatum. Pembentukan cincin warna hijau menunjukkan adanya saponin (Pratama et al., 2012).
Pengaruh Konsentrasi dan Waktu Elisitasi Asam Salisilat terhadap Luas Noda Saponin pada Ekstrak Kalus Ginseng Jawa (Talinum paniculatum)

Pengaruh elisitasi terhadap biosintesis saponin dalam ekstrak kalus T.paniculatum pada berbagai konsentrasi dan waktu elisitasi ditunjukkan melalui histogram pada Gambar 4.

\section{Pembahasan \\ Induksi Kalus Ginseng Jawa (Talinum paniculatum Gaertn.)}

Kalus merupakan kumpulan sel-sel yang belum mengalami diferensiasi dan masih aktif membelah secara terus menerus (Sudarmadji, 2008). Kalus pada umumnya terbentuk sebagai respon terhadap perlukaan pada eksplan saat proses inokulasi. Pertumbuhan kalus selanjutnya merupakan pengaruh dari interaksi antara fitohormon endogen dan ZPT auksin dan sitokinin yang ditambahkan ke dalam media pertumbuhan kultur. Hal ini sesuai dengan kalus yang terbentuk dalam penelitian ini dimana inisiasi pembentukan kalus terjadi pada bekas irisan eksplan karena sebagian sel pada permukaan irisan tersebut mengalami proliferasi. Pengaruh penambahan ZPT 2 $\mathrm{mg} / \mathrm{L}$ 2,4-D dan $3 \mathrm{mg} / \mathrm{L}$ kinetin ke dalam medium MS terbukti dapat menghasilkan kalus yang remah dan berwarna hijau kecoklatan (Gambar 1). 


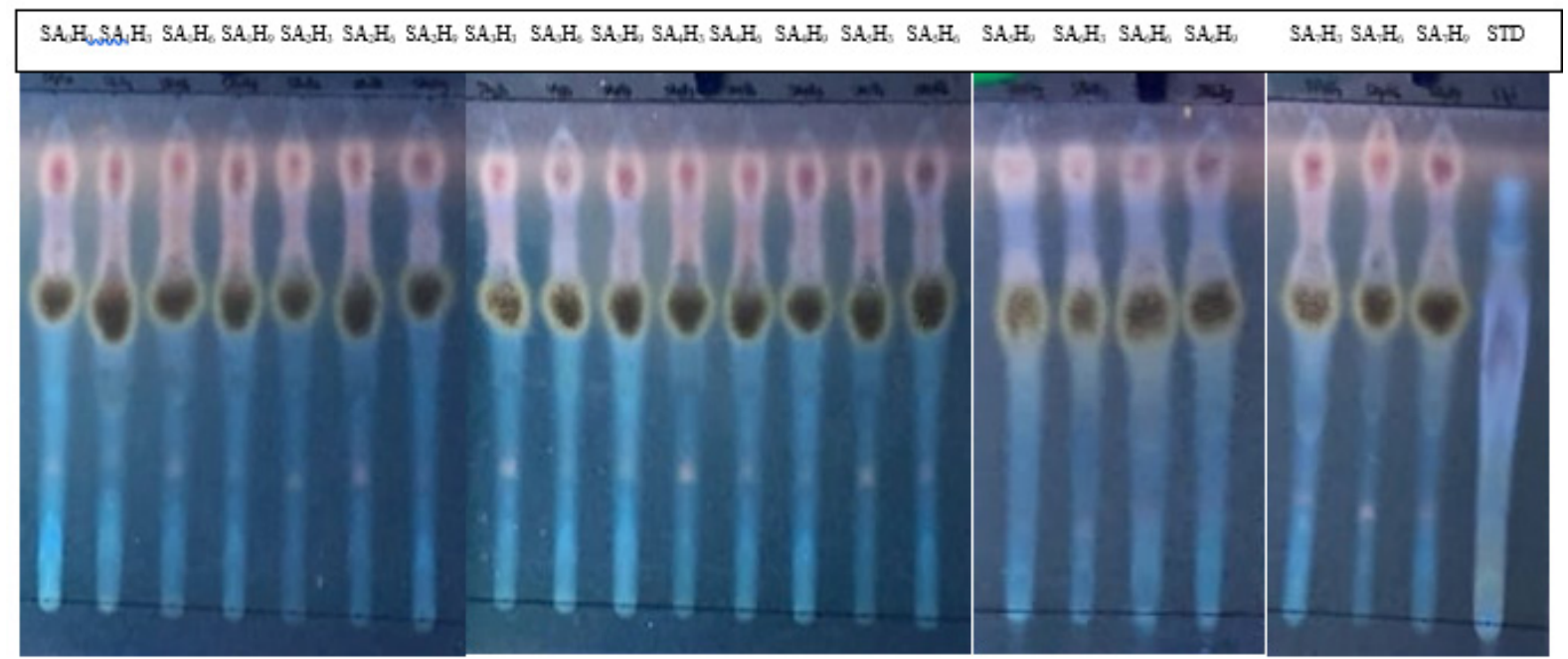

Gambar 3. Identifikasi Saponin menggunakan Kromatografi Lapis Tipis (KLT).

Keterangan : Konsentrasi asam Salisilat : $\mathrm{SA}_{0}=0 \mathrm{mM}, \mathrm{SA}_{1}=0,05 \mathrm{mM}, \mathrm{SA}_{2}=0,10 \mathrm{mM}, \mathrm{SA}_{3}=0,15 \mathrm{mM}, \mathrm{SA}_{4}=0,20 \mathrm{mM}$, $\mathrm{SA}_{5}=0,25 \mathrm{mM}_{2} \mathrm{SA}_{6}=0,30 \mathrm{mM}, \mathrm{SA}_{7}=0,35 \mathrm{mM}$. Waktu Inkubasi $\mathrm{H}_{0}=0$ Hari, $\mathrm{H}_{3}=3$ Hari, $\mathrm{H}_{6}=6 \mathrm{Hari}_{1} \mathrm{H}_{9}=9$ Hari

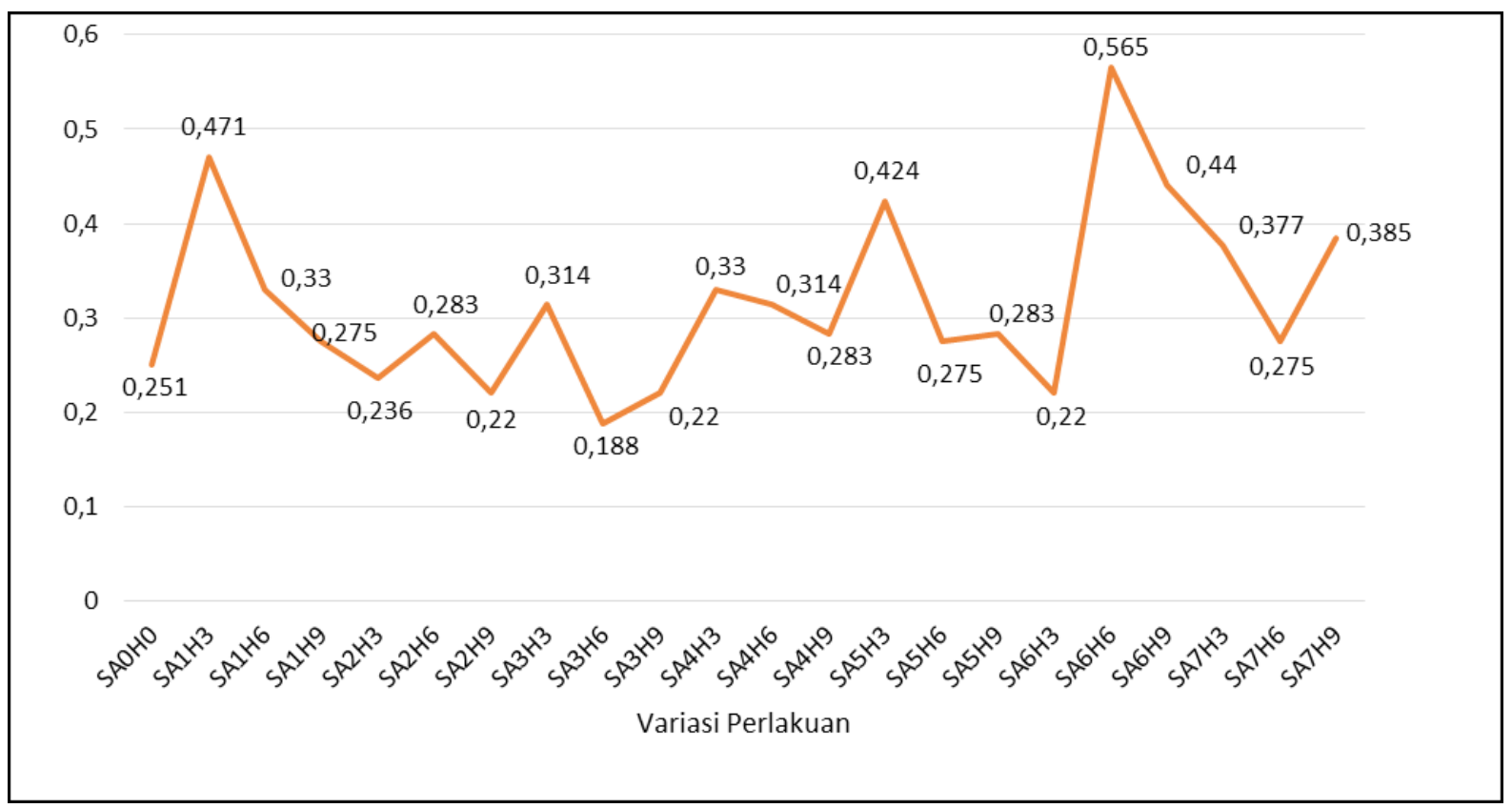

Gambar 4. Grafik Pengaruh Konsentrasi Asam Salisilat dan Waktu Elisitasi terhadap Luas Noda Saponin pada Ekstrak kalus ginseng Jawa (Talinum paniculatum)

Keterangan : Konsentrasi asam Salisilat: $\mathrm{SA}_{0}=0 \mathrm{mM}, \mathrm{SA}_{1}=0,05 \mathrm{mM}, \mathrm{SA}_{2}=0,10 \mathrm{mM}, \mathrm{SA}_{3}=0,15 \mathrm{mM}, \mathrm{SA}_{4}=0,20 \mathrm{mM}$, $\mathrm{SA}_{5}=0,25 \mathrm{mM}, \mathrm{SA}_{6}=0,30 \mathrm{mM}, \mathrm{SA}_{7}=0,35 \mathrm{mM}$. Waktu Inkubasi $\mathrm{H}_{0}=0$ Hari, $\mathrm{H}_{3}=3$ Hari, $\mathrm{H}_{6}=6 \mathrm{Hari}_{9} \mathrm{H}_{9}$ $=9$ hari

Pemilihan fase pertumbuhan kalus merupakan salah satu faktor penting yang harus dipertimbangkan dalam melakukan elisitasi. Trimulyono et al. (2004), menyatakan bahwa pertumbuhan kalus terbagi menjadi 3 fase yaitu fase lag, eksponensial dan stasioner. Dari ketiga fase tersebut, fase stasioner merupakan fase yang ideal untuk memulai produksi metabolit sekunder karena sel sudah mulai berhenti membelah dan metabolit primer dapat menjadi precursor metabolism sekunder. Hal ini sejalan dengan hasil penelitian Wang et al.(2015), yang menunjukkan bahwa kalus $H$. perforatum dalam kultur supsensi sel yang memasuki fase stasioner menunjukkan produksi 
flavonoid tertinggi sebesar $16 \mathrm{mg} / \mathrm{g}$ berat kering kalus dibandingkan pada kalus fase lag dan eksponensial. Berdasarkan hasil penelitian tersebut peningkatan biomassa kalus berkorelasi dengan peningkatan produksi flavonoid dalam kultur suspensi sel yang dielisitasi menggunakan metil jasmonat.

Kalus yang digunakan untuk elisitasi dalam penelitian ini merupakan kalus yang telah memasuki fase stasioner pada hari ke-58 yang merupakan hasil pengamatan penelitian terdahulu (Wijaya et al., 2019). Kalus yang terbentuk bertekstur remah dengan warna hijau kecoklatan (Gambar 1). Warna kecoklatan pada kalus merupakan tanda kalus mengalami penuaan atau sudah masuk fase stasioner (Setiawati et al., 2020). Selain itu, perbedaan warna kalus dapat dipengaruhi oleh pigmentasi, intensitas cahaya, dan sumber eksplan dari bagian tanaman yang berbeda, jaringan kalus yang dihasilkan dari suatu eksplan biasanya memunculkan warna yang berbeda-beda (Lutfiana, 2013). Kalus yang telah masuk fase stasioner (hari ke-58) selanjutnya disubkultur ke dalam media MS yang mengandung asam salisilat variasi konsentrasi $0 \mathrm{mM} ; 0,05$ $\mathrm{mM} ; 0,1, \mathrm{mM} ; 0,15 \mathrm{mM} ; 0,2 \mathrm{mM} ; 0,25 \mathrm{mM}$ ; 0,3 $\mathrm{mM}$ dan $0,35 \mathrm{mM}$ dan variasi waktu elisitasi (0- 9 hari).

Pengaruh Konsentrasi dan Waktu Elisitasi Asam Salisilat terhadap Pertumbuhan Kalus Ginseng Jawa (Talinum paniculatum)

Biomassa kalus digunakan untuk dapat mengukur pengaruh elisitasi terhadap pertumbuhan kalus. Pengukuran dilakukan dengan menimbang berat kering kalus. Data yang diperoleh disajikan pada Gambar 2.

Berdasarkan gambar 2 dapat dilihat bahwa biomassa kontrol lebih rendah $(0,054$ gram) dibandingkan biomassa pemberian perlakuan asam salisilat pada berbagai konsentrasi dan waktu elisitasi $(0,056$ 0,069 gram). Hal ini menunjukkan bahwa pemberian asam salisilat pada berbagai konsentrasi dan waktu inkubasi berpengaruh terhadap peningkatan biomassa kalus $T$. paniculatum. Peningkatan biomassa kalus oleh penambahan asam salisilat tersebut dapat disebakan karena asam salisilat merupakan susbtansi analog hormon yang berperan penting dalam regulasi pertumbuhan dan perkembangan tanaman. Selain itu, asam salisilat juga terlibat dalam mekanisme pertahanan tumbuhan saat terjadi infeksi pathogen dan ketika tanaman mengalami cekaman lingkungan (Anusha et al., 2016).

\section{Hasil Uji Saponin Kromatografi Lapis Tipis (KLT)}

Hasil pengamatan pada plat KLT dituangkan dalam tabel 2 yang berisikan nilai Rf dan luas noda. Standar yang digunakan pada penelitian ini adalah saponin $5 \%$ dalam etanol. Nilai Rf standar saponin adalah 0,66 dan nilai Rf pada kontrol serta perlakuan pemberian asam salisilat nilai Rf berkisar pada 0,61 - 0,66. Hal ini menunjukkan bahwa tidak ada perbedaan nyata antara nilai Rf standar dan perlakuan, sehingga didiuga bahwa noda yang terdapat pada setiap perlakuan merupakan senyawa saponin. Nilai Rf tertinggi terdapat pada konsentrasi asam salisilat $0,25 \mathrm{mM}$ dan waktu inkubasi 3 hari $\left(\mathrm{SA}_{5} \mathrm{H}_{3}\right)$. Penentuan biosintesis saponin secara semi kuantitatif dilakukan berdasarkan pengukuran luas noda yang terbentuk. Berdasarkan hasil pengamatan pada (Tabel 1 dan Gambar 4.) menunjukkan bahwa luas noda saponin tertinggi adalah pada konsentrasi asam salisilat $0,30 \mathrm{mM}$ dengan waktu inkubasi 6 hari $\left(\mathrm{SA}_{6} \mathrm{H}_{6}\right)$ sebesar $\left(0,565 \mathrm{~cm}^{2}\right)$.

Pengaruh Konsentrasi dan Waktu Elisitasi Asam Salisilat terhadap Luas Noda Saponin pada Ekstrak Kalus Ginseng Jawa (Talinum paniculatum)

Pemilihan jenis elisitor, konsentrasi elisitor serta waktu elisitasi merupakan faktor-faktor yang harus diperhatikan untuk meningkatkan efektifitas biosintesis metabolit sekunder dalam kultur in vitro (Halder et al., 2019). Oleh karena itu dalam penelitian ini dilakukan optimasi terhadap jenis elisitor asam salisilat, variasi konsentrasi asam salisilat $(0,05-0,3 \mathrm{mM})$ dan variasi waktu elisitasi (3 - 9 hari) terhadap kandungan saponin dalam kultur kalus T. paniculatum pada fase stasioner. 
Berdasarkan hasil yang disajikan pada Gambar 4. menunjukkan bahwa pemberian asam salisilat pada berbagai konsentrasi serta waktu elisitasi menghasilkan kandungan saponin (berdasarkan pendekatan luas noda yang terbentuk) yang lebih besar jika dibandingkan dengan kontrol $\left(0,251 \mathrm{~cm}^{2}\right)$. Luas noda yang terbesar $\left(0,565 \mathrm{~cm}^{2}\right)$ dihasilkan pada kalus yang diberi asam salisilat sebesar 0,3 mM dengan waktu elisitasi selama 6 hari. Berdasarkan hasil tersebut dapat disimpulkan bahwa pemberian konsentrasi asam salisilat sebesar 0,05-0,35 $\mathrm{mM}$ pada kultur kalus serta waktu elisitasi selama (3 -9 hari) telah mampu memicu stres pada kalus T. paniculatum sehingga menstimulasi pembentukan metabolit sekunder sebagai mekanisme pertahanan sel. Hasil penelitian yang samajuga dilaporkan oleh Anusha et al. (2016), dimana peningkatan konsentrasi asam salisilat (25 $-250 \mu \mathrm{M})$ dengan waktu elisitasi (24 - 72 jam) pada kultur suspensi kalus Celastrus paniculatus menghasilkan peningkatan produksi total fenol jika dibandingkan dengan kontrol.

\section{Kesimpulan}

Kesimpulan yang diperoleh dalam penelitian ini adalah penambahan konsentrasi asam salisilat sebesar $(0,05$ 0,35 mM) dan waktu elisitasi (3-9 hari) pada kultur kalus T.paniculatum berpengaruh terhadap peningkatan biomassa kalus $(0,056$ - 0,069 gram) dibandingkan kontrol (0,054 gram). Selain itu penambahan asam salisilat pada variasi konsentrasi dan waktu elisitasi juga terbukti berpengaruh dalam meningkatkan kandungan saponin dalam kalus dibandingkan kontrol $\left(0,251 \mathrm{~cm}^{2}\right)$ yang ditunjukkan melalui luas noda saponin sebesar $\left(0,22-0,565 \mathrm{~cm}^{2}\right)$. Kandungan saponin tertinggi dihasilkan pada kalus yang diberi asam salisilat konsentrasi $0,3 \mathrm{mM}$ dengan waktu elisitasi selama 6 hari.

\section{Daftar Pustaka}

Anusha, T. S., Joseph, M.V., \& Elyas K. K. (2016). Callus Induction and Elicitation in Callus Cell Suspension Culture of Celastrus paniculatus-wild, and Endangered Medicinal Plant in India. Pharmacognosy Journal, 8(5), 471-475.
Efferth, T. (2019). Biotechnology Applications of Plant Callus Cultures. Engineering (5),50-59.

Faizal, A. \& Sari, A. V. (2019). Enhancement of saponin accumulation in adventitious. African Journal of Biotechnology, 18(6), 130-135,.

Halder, M., Sharkar, S., \& Jha, S. (2019). Elicitation: A Biotechnological Tool For Enhanced Production Of Secondary Metabolites In Hairy Root Cultures. Engineering Life Science, 19(12), 880-895.

Lutfiana. (2013). Uji Aktivitas Antiimflamasi Eksrtak Daun Kelor (Moringa oleifera Lamk.) Dengan Metode Stabilisasi Membrane Sel Darah Merah Dengan Metode In vitro. [Skripsi]. Jakarta : UIN Syarif Hidayatullah

Manuhara, Y.S. W., Kristanti, A. N., \& Utami ESW. (2015). Optimization of culture conditions of Talinum paniculatum Gaertn. adventitious roots in balloon type bubble bioreactor using aeration rate and initial inoculum density. Asian Journal of Biological Sciences, 8, 83-92.

Pratama, M. A., Hosea J. E., \& Jovie M. D. (2012). Isolasi dan Identifikasi Senyawa Saponin Dari Ekstrak Metanol Batang Pisang Ambon (Musa paradisiaca var. sapientum L.). [online] Pharmacon, 1(2), 86-92.

Purwianingsih, W., Febri, S., \& Kusdianti. (2016). Formation flavonoid secondary metabolites in callus culture of Chrysanthemum cinerariefolium as alternative provision medicine. AIP Conference Proceedings 1708.

Setiawati, T., Ayalla, A., Nurzaman, M., Kusumaningtyas, V., \& Bari, I. (2020). Analisis Metabolit Sekunder Kultur Pucuk, Kalus, dan Tanaman Lapang Chrysanthemum morifolium Ramat. Jurnal Ilmu Dasar, 21(1), 1-10.

Setyani, W., Setyowati, H. \& Ayuningtyas, D.(2016). Pemanfaatan Ekstrak Terstandardisasi Daun Som Jawa (Talinum paniculatum). Jurnal Farmasi Sains Dan Komunitas, 13(1), 44-51.

Sudarmadji. (2003). Penggunaan Benzil Amino Purine pada Pertumbuhan 
Kalus Kapas Secara In Vitro. Buletin Teknik Pertanian (8).

Trimulyono, G., Solichatun., \& Marliana S. D. (2014). Pertumbuhan Kalus dan Kandungan Minyak Atsiri Nilam (Pogostemon cablin (Blanco) Bth.) dengan Perlakuan Asam aNaftalen Asetat (NAA) dan Kinetin. Biofarmasi, 2(1), 9-14.

Wang, J., Qian, J., Yao, L., \& Lu, Y. (2015). Enhanced Production of Flavonoid by Methyl Jasmonate Elicitation in Cell Suspension Culture of Hypericum perforatum. Bioresources dan Bioprocessing (2)5, 1-9.

Wijaya. R., Restiani. R., \& Aditiyarini. D. (2020). Pengaruh Kitosan terhadap Produksi Saponin Kultur Kalus Daun Ginseng Jawa (Talinum paniculatum (Jacq.) Gaertn.). Prosiding Seminar Nasional Biologi. 5-1 